Artikel Penelitian

\title{
Kualitas Tempe Menggunakan Rhizopus microsporus TB23, R. microsporus TB32, dan R. microsporus TB55 yang Berasal dari Inokulum "Daun Waru"
} Quality of Tempeh using Rhizopus microsporus TB23, R. microsporus TB32, and R. microsporus TB55 Originating from the "Waru Leaf" Inoculum

Tati Barus ${ }^{1 *}$, Reza Arif Rahman²

1Program Studi Magister Bioteknologi, Fakultas Teknobiologi, Universitas Katolik Indonesia Atma Jaya, Jakarta 2Program Studi Teknologi Pangan, Fakultas Teknobiologi, Universitas Katolik Indonesia Atma Jaya, Jakarta "Korespondensi dengan penulis (tati.barus@atmajaya.ac.id)

Artikel ini dikirim pada tanggal 14 Juli 2020 dan dinyatakan diterima tanggal 20 Februari 2021. Artikel ini juga dipublikasi secara online melalui https://ejournal2.undip.ac.id/index.php/jatp. Hak cipta dilindungi undang-undang. Dilarang diperbanyak untuk tujuan komersial.

Diproduksi oleh Indonesian Food Technologists ${ }^{\circledR}$ (C2021

\begin{abstract}
Abstrak
Rhizopus microsporus TB23, R. microsporus TB32, dan R. microsporus TB55 telah berhasil diisolasi dari inokulum "daun waru" terbukti dapat menghasilkan tempe dengan kualitas yang baik namun masih pada skala kecil di laboratorium. Oleh sebab itu, penelitian ini bertujuan untuk membandingkan kualitas tempe yang diproduksi dengan $R$. microsporus TB23, $R$. microsporus TB32, dan $R$. microsporus TB55 pada skala pengrajin tempe. Pembuatan tempe dilakukan di produsen tempe di Serpong-Tangerang. Pembuatan tempe dilakukan dengan menggunakan $300 \mathrm{~g}$ kedelai yang diinokulasi dengan $R$. microsporus TB23, $R$. microsporus TB32, $R$. microsporus TB55 dan inokulum komersial secara terpisah. Selanjutnya, uji organoleptik, pengukuran aktivitas antioksidan, analisis proksimat dilakukan terhadap setiap tempe yang berhasil diproduksi. Hasil penelitian ini menunjukkan bahwa cita rasa tempe menggunakan $R$. microsporus TB32 adalah yang paling disukai panelis. $R$. microsporus TB23, $R$. microsporus TB32, dan $R$. microsporus TB55 dapat menghasilkan tempe dengan kualitas yang sama dengan penelitian sebelumnya dan sesuai dengan syarat mutu tempe berdasarkan SNI 31144:2015 kecuali dalam hal warna. $R$. microsporus TB23, R. microsporus TB32, dan $R$. microsporus TB55 menghasilkan tempe berwarna kekuningan. Oleh sebab itu, informasi tentang warna kuning tersebut perlu dikaji lebih lanjut. Kesimpulannya, $R$. microsporus TB32 adalah inokulum yang paling baik untuk menghasilkan tempe dan dikembangkan sebagai inokulum tempe jika dibandingkan dengan $R$. microsporus TB23 dan $R$. microsporus TB55.
\end{abstract}

Kata kunci: Rhizopus, antioksidan, inokulum, organoleptik, kualitas, tempe.

\section{Abstract}

Rhizopus microsporus TB23, R. microsporus TB32, and R. microsporus TB55 have been successfully isolated from the "hibiscus leaf" resulting good quality of tempeh but still on laboratory scale. Therefore, this study aims to compare the quality of tempeh produced with $R$. microsporus TB23, $R$. microsporus TB32, and $R$. microsporus TB55 from the "waru leaf" inoculum in small scale production. Tempe was made in a small scale tempe producer in Serpong-Tangerang. Tempeh was made from $300 \mathrm{~g}$ of soybeans. Each tempeh was inoculated with R. microsporus TB23, R. microsporus TB32, R. microsporus TB55 and commercial inoculum, respectively. Organoleptic test, measurement of antioxidant activity, and proximate analysis were carried out for each tempeh to analyze its quality. The results of this study indicate that the taste of tempeh produced by $R$. microsporus TB32 was the most preferred by panelists. R. microsporus TB23, R. microsporus TB32, and R. microsporus TB55 produced tempe with similar quality as previous studies and in accordance with SNI 31144:2015 except color performance. R. microsporus TB23, $R$. microsporus TB32, and R. microsporus TB55 produced yellowish-colored tempeh. In conclusion, $R$. microsporus TB32 was better tempeh inoculum than $R$. microsporus TB23 and R. microsporus TB55.

Keywords: Rhizopus, antioxidant, inoculum, organoleptic, quality, tempeh.

\section{Pendahuluan}

Pangan fermentasi bukan saja sebagai sumber nutrisi, namun mengandung mikroba dan senyawa bioaktif yang penting bagi kesehatan (Astuti et al., 2000). Salah satu jenis pangan fermentasi yang baik untuk kesehatan adalah tempe kedelai (tempe) yang merupakan makanan fermentasi khas Indonesia dan telah diproduksi serta dikonsumsi di berbagai negara (Aderibigbe and Osegboun 2006). Tempe mengandung vitamin B12 yang jarang ditemukan pada pangan nabati (Maria et al., 2020). Roubos van den Hill et al. (2009) melaporkan bahwa tempe mengandung senyawa yang dapat mencegah pelekatan Escherichia coli ETEC pada epitel usus sehingga dapat mencegah diare. Selain itu, tempe dapat meningkatkan fungsi kognitif pada orang tua lanjut usia (Handajani et.al. 2020) dan menambah mikrobiota usus yang baik (Stephanie et al., 2019). Tempe juga mengandung isoflavon yang dapat mencegah dan menghambat perkembangan sel kanker (Sarkar and Li 2002). Fermentasi tempe menggunakan $R$. oryzae meningkatkan kandungan isoflavon aglikon dibandingkan dengan kedelai yang tidak difermentasi. 
Kiers et al. (2000) melaporkan juga bahwa proses fermentasi dalam produksi tempe dapat meningkatkan daya cerna sehingga lebih optimal dalam proses penyerapan nutrisinya.

Kualitas tempe dipengaruhi oleh cara pembuatan (Kadar et al., 2020), jenis kacang kedelai (Astawan et al., 2020a), dan mikroba (Barus et al., 2019a) yang berperan dalam proses fermentasi. Rhizopus spp. merupakan mikroba utama pada fermentasi tempe (Hartanti et al., 2015). Miselium Rhizopus spp. mengikat keping kedelai satu dengan yang lainnya sehingga menciptakan tekstur tempe yang kompak dan tetap utuh saat dipotong (Barus et al., 2019b). Masing masing spesies Rhizopus spp. memiliki kemampuan sporulasi, ketahanan terhadap kontaminan, dan kepadatan miselium yang berbedabeda (Nout and Rombouts 1990). Perbedaan galur yang berbeda dari spesies Rhizopus spp. dapat menghasilkan tekstur, rasa, dan nilai gizi yang berbeda (Barus et al., 2019a).

Dahulu spesies Rhizopus spp. yang digunakan pada fermentasi tempe di Indonesia sangatlah beragam, seperti $R$. microsporus, $R$. rhizopodiformis, dan $R$. chinensis. Namun, saat ini Rhizopus spp. yang ditemukan pada tempe dari beberapa daerah di Indonesia didominasi oleh $R$. microsporus yang berasal dari inokulum komersial yang sama (Hartanti et al., 2015). Oleh sebab itu, perlu dikembalikan keragaman Rhizopus spp. yang digunakan pada fermentasi tempe. Barus et al. (2019c) telah berhasil mengisolasi dan mengidentifikasi $R$. microsporus TB23, $R$. microsporus TB32, dan $R$. microsporus TB55 dari inokulum "daun waru" yang berasal dari beberapa daerah di Jawa Tengah. Barus et al. (2019b) telah melaporkan ketiga $R$. microsporus tersebut menghasilkan tempe yang memenuhi syarat mutu yang diatur pada SNI 2015. Namun, informasi tersebut masih terbatas pada tempe yang difermentasi pada skala laboratorium. Oleh sebab itu, penelitian ini bertujuan untuk membandingkan potensi dari $R$. microsporus TB23, $R$. microsporus TB32, dan $R$. microsporus TB55 dalam menentukan kualitas tempe yang diproduksi pada skala produksi di pengrajin tempe. Penelitian ini bermanfaat terhadap penambahan ragam jenis $R$. microsporus yang dapat digunakan dalam fermentasi tempe di Indonesia.

\section{Materi dan Metode \\ Materi}

Penelitian ini menggunakan $R$. microsporus TB23, $R$. microsporus TB32, $R$. microsporus TB55 yang diisolasi dari inokulum "daun waru" dan inokulum komersial (Raprima, Bandung). Bahan-bahan yang digunakan adalah kedelai yang diperoleh dari pasar modern Intermoda-BSD-Tangerang, asam asetat, etanol (Emsure, Germany), garam fisiologis 0,85\% (b/v) (Merck, Germany), Potato Dextrose Agar (PDA) (Oxoid, USA), kertas saring $110 \mathrm{~mm}$ (Whatman) (Merck, Germany), dan 2,2-diphenyl-1-picrylhydrazyl (DPPH) (Sigma-Aldrich, Germany). Peralatan yang digunakan terdiri atas hemasitometer (Merck, Germany), freeze dryer (Labfrezz type F, China), incubator shaker (Memmert, UK), mikroskop cahaya (Olympus CX 21,
Japan), inkubator (Memmert INE 400, UK), vortex (Thermolyne Tipe 37680 Mixer, USA), spektrofotometer (Optima SP 3000-plus, Japan), dan timbangan analitik (Shimadzu ATX 224, Japan).

\section{Pembuatan Inokulum Tempe}

Masing-masing $R$. microsporus TB23, $R$. microsporus TB32, dan $R$. microsporus TB55 ditumbuhkan pada Potato Dextrose Agar (PDA) selama 8 hari pada suhu $30{ }^{\circ} \mathrm{C}$ secara aerob hingga terbentuk spora. Spora yang tumbuh dipanen dengan menambahkan $5 \mathrm{ml}$ garam fisiologis 0,85 \% (b/v). Selanjutnya, pembuatan inokulum dilakukan dengan mengikuti metode Astawan et al. (2017). Inokulum ini selanjutnya digunakan pada pembuatan tempe (Tabel 1).

Tabel 1 Kode tempe, bobot kedelai dan inokulum yang digunakan pada pembuatan tempe

\begin{tabular}{lcc}
\hline Kode tempe & $\begin{array}{c}\text { Bobot } \\
\text { kedelai }(\mathrm{g})\end{array}$ & Inokulum \\
\hline Tempe TB23 & 300 & R. microsporus TB23 $(0,7 \mathrm{~g})$ \\
Tempe TB32 & 300 & R. microsporus TB32 $(0,7 \mathrm{~g})$ \\
Tempe TB55 & 300 & R. microsporus TB55 $(0,7 \mathrm{~g})$ \\
Tempe K & 300 & komersial $(0,7 \mathrm{~g})$ \\
\hline
\end{tabular}

\section{Pembuatan Tempe}

Proses pembuatan tempe dilakukan dengan menggunakan metode Pekalongan (Barus et al., 2008) di pengrajin tempe di Serpong-Tangerang. Inokulum Tempe TB23, Tempe TB32, Tempe TB55 dan Tempe K diproduksi menggunakan $300 \mathrm{~g}$ kedelai dengan menggunakan inokulum sesuai dengan Tabel 1. Tempe dikemas pada plastik berlubang dan diinkubasi pada suhu $30^{\circ} \mathrm{C}$ selama 48 jam. Masing masing pembuatan tempe diulang sebanyak tiga kali.

\section{Uji Organoleptik Tempe}

Uji organoleptik dilakukan oleh 30 orang panelis tidak terlatih. Uji organoleptik dilakukan meliputi warna, aroma, tekstur, rasa, dan after taste tempe sesuai metode Lawless and Heymann (2010). Masing masing panelis diminta memberikan penilaian cita rasa tempe dengan memilih angka 1 (sangat tidak suka), 2 (tidak suka), 3 (suka), dan 4 (sangat suka). Analisis organoleptik diulang sebanyak tiga kali. Sampel tempe yang disajikan kepada panelis merupakan tempe yang telah dikukus selama 10 menit dengan ukuran $1 \times 1 \times 2$ $\mathrm{cm}$ dalam kondisi sudah dingin. Uji organoleptik tempe diulang sebanyak tiga kali.

\section{Pembuatan Tepung Tempe}

Pembuatan tepung tempe dilakukan mengikuti metode Barus et al. (2019a). Masing masing jenis tempe sebanyak $200 \mathrm{~g}$ dipotong kecil lalu masukkan ke freeze dryer untuk dikeringkan pada suhu $-80^{\circ} \mathrm{C}$ selama 13 jam. Selanjutnya, tempe hasil freeze dryer dihaluskan dengan blender hingga dihasilkan tepung yang siap digunakan untuk analisis proksimat dan aktivitas antioksidan. 


\section{Analisis Proksimat}

Analisis proksimat tempe dilakukan di PT Saraswanti Indo Genetech Bogor. Analisis proksimat menggunakan standar Internasional AOAC edisi ke-19 tahun 2012 (AOAC, 2012). Pengukuran kadar air, lemak, dan abu dilakukan dengan metode Gravimetri. Pengukuran kadar protein dilakukan dengan metode analisis auto destruksi dengan perangkat $\mathrm{Kjeltec}^{\mathrm{TM}}$. Pengukuran kadar karbohidrat dengan cara by difference (AOAC, 2012).

\section{Pengukuran Aktivitas Antioksidan}

Pengukuran aktivitas dari tempe dilakukan dengan menggunakan tepung tempe sesuai dengan metode Ningsih et al. (2018) yang telah dimodifikasi. Sebanyak $1 \mathrm{~g}$ tepung tempe dimasukkan ke dalam conical tube $50 \mathrm{ml}$ dan ditambahkan dengan $10 \mathrm{ml}$ etanol absolut. Campuran kemudian dimaserasi di dalam water-bath dengan suhu $65{ }^{\circ} \mathrm{C}$ selama 1 jam. Selanjutnya, campuran diputar dengan menggunakan sentrifugasi pada kecepatan 5000 rpm selama 10 menit. Bagian yang diukur antioksidannya adalah bagian supernatan sebanyak $1 \mathrm{ml}$. Pengukuran aktivitas antioksidan diulang sebanyak 3 kali dan dinyatakan dalam persen.

\section{Analisis Data}

Data hasil uji organoleptik dan hasil pengukuran aktivitas antioksidan dianalisis dengan metode analysis of variance (ANOVA). Jika hasil uji ANOVA menunjukkan perbedaan yang berbeda nyata secara signifikan maka dilanjutkan dengan uji lanjutan Duncan Multiple Range Test dengan taraf signifikansi 5\%. Analisis statistik dihitung menggunakan software Statistical Package for the Social Science (SPSS) seri ke-24.

\section{Hasil dan Pembahasan \\ Pembuatan Tempe}

Pembuatan tempe berhasil dilakukan menggunakan inoculum $R$. microsporus TB23 (Tempe TB23), inokulum $R$. microsporus TB32 (Tempe TB32), inokulum $R$. microsporus TB55 (Tempe TB55) dan inokulum komersial (Tempe K) (Tabel 1). Semua tempe tersebut (Gambar 1) berbau khas tempe dan bertekstur padat sehingga saat dipotong tempe tetap utuh. Berdasarkan parameter bau dan tekstur maka semua tempe tersebut memenuhi syarat mutu tempe yang ditetapkan pada SNI 31144:2015 yang menyatakan bahwa tempe yang baik harus berbau khas tempe tanpa berbau amoniak dan bertekstur padat sehingga saat dipotong tempe tetap utuh (tidak rontok).

Warna pada tempe ditentukan oleh warna miselium yang dimiliki masing masing Rhizopus yang digunakan yang digunakan. Berdasarkan syarat mutu tempe SNI 31144:2015 maka warna tempe yang baik adalah yang berwarna putih. Oleh sebab itu, berdasarkan kriteria warna maka hanya Tempe $\mathrm{K}$ yang berwarna putih yang memenuhi kriteria SNI 2015. Tempe TB23, Tempe TB32, dan Tempe TB55 berwarna kekuningan dan warna yang paling kuning ditemukan pada Tempe TB32 (Gambar 1). Warna kuning pada tempe tersebut telah dilaporkan juga oleh Barus et al., (2019b). Dengan demikian maka warna kuning tersebut konsisten terbentuk pada saat dilakukan pembuatan tempe menggunakan $R$. microsporus TB23, $R$. microsporus TB32, dan $R$. microsporus TB55 pada kondisi terkontrol di laboratorium maupun di level pengrajin. Warna kuning pada kedua tempe tersebut kemungkinan karena bagian globula sporangium dari $R$. microsporus TB23 dan $R$. microsporus TB32 berwarna kekuningan (Jennesen et al., 2008) atau karena adanya pigmen $\beta$-karoten yang terbentuk pada kedua galur $R$. microsporus (Sudaryatiningsih dan Supyani, 2009; Schipper et al., 1985). $\beta$-karoten tersebut bersifat antioksidan yang dapat menangkal radikal bebas (Fiedor and Burda, 2014). Oleh sebab itu warna kuning pada kedua galur $R$. microsporus tersebut menarik untuk dikaji lebih lanjut.

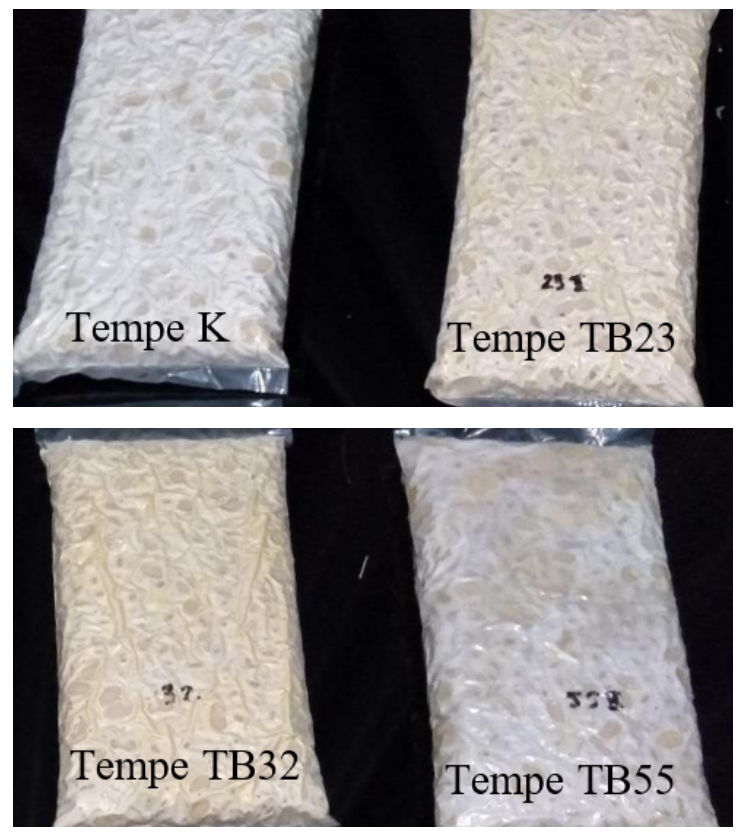

Gambar 1. Tempe hasil fermentasi menggunakan beberapa jenis inokulum. Tempe K: menggunakan inokulum komersial. Tempe TB23: menggunakan inokulum $R$. microsporus TB 23. Tempe TB32: menggunakan inokulum $R$. microsporus TB32. Tempe TB55: menggunakan inokulum $R$. microsporus TB55.

\section{Uji Organoleptik Tempe}

Tabel 2 menunjukkan hasil uji organoleptik Tempe K, Tempe TB23, Tempe TB32, dan Tempe TB55. Hasil uji organoleptik (Tabel 2) menunjukkan bahwa penerimaan panelis terhadap Tempe $\mathrm{K}$, Tempe TB23, dan Tempe TB55 konsisten dengan hasil penelitian sebelumnya (Barus et al., 2019b). Dimana penerimaan panelis terhadap ketiga jenis tempe tersebut tidak berbeda nyata secara signifikan. Berbeda dengan Tempe TB32 yang menjadi paling disenangi panelis pada penelitian ini.

Mikroorganisme dinilai berpengaruh terhadap kualitas bahan pangan (Endrawati et al., 2017). Barus et al. (2009a) telah juga melaporkan bahwa mikroorganisme pada tempe berperan penting dalam menentukan kualitas pada tempe. Jenis Rhizopus yang 
digunakan dapat mempengaruhi cita rasa tempe karena masing masing jenis memiliki karakteristik metabolism sendiri (Nout and Kiers 2005). Rhizopus dapat memiliki aktivitas proteolitik yang berbeda yang dapat menyebabkan terbentuknya peptida yang menyebabkan rasa pahit pada bahan pangan. Peptida yang memiliki berat molekul sekitar 2.4 -3.5 kDa (Kim et al., 2003) dan peptida yang berukuran $2 \mathrm{kDa}$ dan $4 \mathrm{kDa}$ (Myong et al., 2004) dapat menyebabkan rasa pahit. Oleh sebab itu, menarik untuk dianalisis lebih lanjut tentang karakter proteolitik $R$. microsporus TB23, $R$. microsporus TB32, dan $R$. microsporus TB55.

Tabel 2 Hasil uji organoleptik tempe

\begin{tabular}{|c|c|c|c|c|}
\hline Parameter & $\begin{array}{c}\text { Tempe } \\
\mathrm{K}\end{array}$ & $\begin{array}{l}\text { Tempe } \\
\text { TB23 }\end{array}$ & $\begin{array}{l}\text { Tempe } \\
\text { TB32 }\end{array}$ & $\begin{array}{l}\text { Tempe } \\
\text { TB55 }\end{array}$ \\
\hline & $3,9 \pm 0,8^{c}$ & $3,6 \pm 0,9^{a b}$ & $3,9 \pm 0,9 b c$ & $3,4 \pm 1,1^{a}$ \\
\hline Teks & $3,5 \pm 1,1^{a b}$ & $3,6 \pm 1,0^{a b}$ & $3,8 \pm$ & $3,3 \pm 1,1^{a}$ \\
\hline Aroma & $3,5 \pm 1,0^{a}$ & $3,5 \pm 1,0^{a}$ & $3,9 \pm 0,8^{b}$ & $3,6 \pm 1,0^{a}$ \\
\hline Rasa & $3,1 \pm 1,1^{a}$ & $3,3 \pm 1,2^{a}$ & $3,7 \pm 0,9^{b}$ & $3,2 \pm 1,2^{a}$ \\
\hline After taste & $3,2 \pm 1,1^{a}$ & $3,2 \pm 1,1^{a}$ & $3,6 \pm 1,0^{b}$ & $3,2 \pm 1,1^{a}$ \\
\hline
\end{tabular}

Keterangan: Angka yang diikuti dengan huruf yang sama dalam satu baris menunjukkan nilai yang tidak berbeda signifikan. Tempe K: inokulum komersial. Tempe TB23: inokulum $R$. microsporus TB23. Tempe TB32: inokulum $R$. microsporus TB32. Tempe TB55: inokulum $R$. microsporus TB55.

Penelitian Barus et al. (2019b) menunjukkan bahwa tempe yang diproduksi dengan $R$. microsporus TB23, $R$. microsporus TB32, dan $R$. microsporus TB55 menunjukkan tingkat kesukaan yang cenderung sama bahkan lebih tinggi dibanding tempe yang dibuat dengan inokulum komersial, dimana dalam penelitian tersebut $R$. microsporus TB55 memiliki nilai yang paling tinggi pada atribut rasa. Pada penelitian ini nilai atribut aroma, rasa, dan after taste tempe TB32 menunjukkan nilai kesukaan yang tertinggi dan berbeda nyata dengan tempe dari inokulum komersial (Tabel 2). Perbedaan hasil dari penelitian ini dan penelitian Barus et al. (2019b) pertamatama bisa disebabkan oleh metode pembuatan yang berbeda. Penelitian Barus et al. (2019b) dilakukan secara steril, sedangkan penelitian ini dilakukan dalam skala pengrajin dimana terdapat pengaruh besar dari komunitas bakteri baik dalam air asam maupun tempat penyimpanan tempe (Nout and Kiers 2005). Selain itu adanya perbedaan kacang kedelai yang digunakan oleh pengrajin dengan yang digunakan juga bisa menjadi penyebab adanya perbedaan rasa pada tempe yang dihasilkan.

\section{Pengukuran Aktivitas Antioksidan}

Figur 1 menunjukkan pengukuran aktivitas antioksidan yang telah berhasil dilakukan menggunakan metoda DPPH. Figur 1 menunjukkan bahwa aktivitas antioksidan Tempe TB23, Tempe TB32 dan Tempe TB55 secara signifikan lebih tinggi dibandingkan dengan Tempe $\mathrm{K}$ yang menggunakan inokulum komersial. Dengan demikian maka Rhizopus microsporus TB23, Rhizopus microsporus TB32 dan Rhizopus microsporus TB55 yang diisolasi dari daun waru dapat menghasilkan tempe dengan aktivitas antioksidan yang tinggi. Antioksidan merupakan senyawa penting karena dapat menangkal radikal bebas yang dapat menyebabkan berbagai jenis penyakit. Makanan fermentasi merupakan salah satu sumber antioksidan alami (Moktan et al., 2008). Aktivitas antioksidan pada tempe dipengaruhi oleh aktivitas mikrob selama proses fermentasi berlangsung dan cara pengolahan saat mau dikonsumsi (Barus at al., 2019d).

Aktivitas antioksidan Tempe TB23, Tempe TB32 dan Tempe TB55 secara signifikan lebih tinggi dibandingkan dengan Tempe K. Hasil penelitian ini sama dengan hasil penelitian Barus et al. (2019b) bahwa ketiga tempe menghasilkan aktivitas yang tinggi. Demikian juga dalam hal warna, Barus et al., (2019b) yang melaporkan bahwa Tempe TB23, Tempe TB32, dan Tempe TB55 berwarna kekuningan saat digunakan sebagai inokulum pada skala laboratorium. Beberapa galur Rhizopus, termasuk $R$. microsporus, mampu menghasilkan pigmen karoten (Schipper et al., 1985). Oleh karena itu maka tingginya aktivitas antioksidan Tempe TB23, Tempe TB32 dan Tempe TB55 kemungkinan disebabkan karena adanya pigmen $\beta$-karoten yang dihasilkan oleh $R$. microporus TB23, $R$. microporus TB32, dan $R$. microporus TB55. Hal ini karena telah dilaporkan bahwa $\beta$-karoten bersifat antioksidan (Fiedor and Burda, 2014). Beberapa galur Rhizopus, termasuk $R$. microsporus mampu menghasilkan pigmen karoten (Schipper et al., 1985).

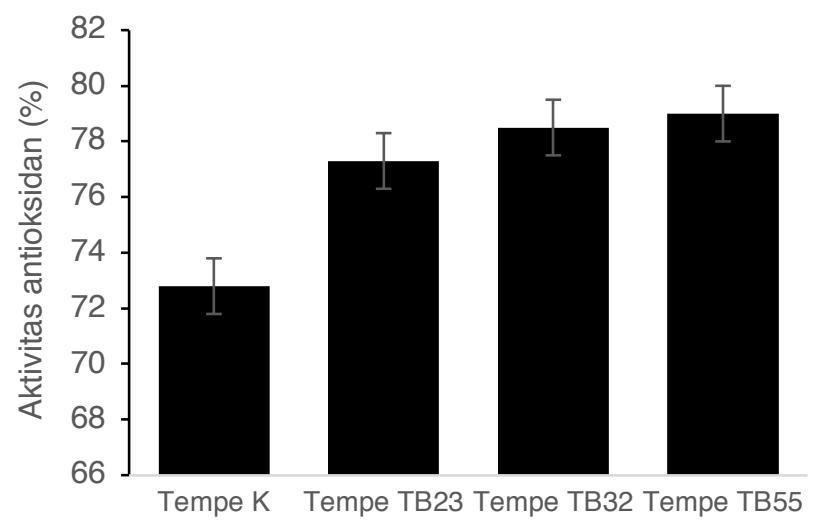

Figur 1. Aktivitas antioksidan tempe menggunakan berbagai inokulum. K: inokulum komersial. TB 23: inokulum $R$. microsporus TB23. TB32: inokulum $R$. microsporus TB32. TB55: inokulum $R$. microsporus TB55.

\section{Komposisi Kimia Tempe}

Tabel 3 menunjukkan hasil proksimat Tempe $\mathrm{K}$, Tempe TB23, Tempe TB32, dan Tempe TB55. Hasil proksimat tempe Tempe TB23, Tempe TB32, dan Tempe TB55 tidak berbeda jauh dengan Tempe $\mathrm{K}$. Kadar protein semua tempe berkisar antara 46,8-48,6\%, sehingga komposisi makromolekul pada tempe yang paling tinggi adalah protein. Oleh sebab itu tempe merupakan sumber protein penting bagi masyarakat Indonesia sehingga tempe juga dianalogikan sebagai pengganti daging untuk sumber protein.

Kedelai merupakan jenis kacang kacangan yang paling banyak dimanfaatkan sebagai bahan pangan 
fermentasi. Seperti tauco, kecap, cheonggukjang (Korea) (Kwon et al., 2009), dawadawa (Terlabie et al., 2006), dan natto (Jepang) (Hsu et al., 2009). Akibat fermentasi, komposisi molekul kedelai diubah menjadi molekul yang lebih sederhana sehingga lebih mudah dicerna (Kiers, 2000). Perubahan tersebut berlangsung secara enzimatik oleh enzim lipase, amilase dan protease dari mikroorganisme yang jumlahnya berlimpah.

Tabel 3. Hasil pengukuran proksimat tempe menggunakan metode analisis AOAC

\begin{tabular}{lcccc}
\hline Komposisi (\%) & \multicolumn{4}{c}{ Tempe } \\
\cline { 2 - 5 } & $\mathrm{K}$ & TB23 & TB32 & TB55 \\
\hline Protein & 47,5 & 46,8 & 48,6 & 47,7 \\
Lemak & 27,7 & 27,4 & 26,1 & 27,8 \\
Karbohidrat & 17,3 & 18,1 & 17,5 & 17,0 \\
Air & 4,70 & 4,80 & 4,80 & 4,90 \\
Abu & 3,00 & 3,00 & 3,10 & 2,90 \\
\hline
\end{tabular}

Keterangan: data diperoleh dari ulangan sebanyak tiga kali.

Komponen protein kedelai secara enzimatik terdegradasi oleh enzim protease menjadi peptida dan asam amino bebas (Handoyo dan Morita 2006). Peptida dan asam amino bebas lebih mudah dicerna dan diabsorbsi tubuh. Peptida mempunyai peranan penting sebagai senyawa bioaktif yang baik untuk kesehatan. Pada tempe ditemukan peptida yang menunjukkan aktivitas antioksidan yang tinggi. Bobot protein pada kedelai yang direbus dan pada tempe tidak jauh berbeda. Kedelai rebus mengandung bobot kedelai yang tidak jauh berbeda dengan tempe. Namun asam amino bebas ditemukan meningkat tajam pada tempe. Hal ini semua menunjukkan kualitas nutrisi tempe lebih baik akibat fermentasi. Namun kualitas ini bisa berbeda antar tempe yang dihasilkan pengrajin karena perbedaan jenis kedelai yang digunakan dan mikroorganisme yang berperan juga sangat bervariasi.

Senyawa anti nutrisi pada tempe menjadi turun dibandingkan kedelai. Penurunan senyawa anti nutrisi ini penting sehingga mineral pada tempe seperti kalsium, dan besi mudah diabsorbsi tubuh karena sudah dalam bentuk bebas. Haron et al. (2010) melaporkan absorbsi kalsium kedelai tidak kalah dengan absorbsi kalsium susu pada orang Malaysia. Oleh sebab itu, selain susu sebagai sumber kalsium yang perlu untuk kesehatan susu maka tempe juga sumber yang baik untuk kalsium.

\section{Kesimpulan}

$R$. microsporus TB23, $R$. microsporus TB32, dan $R$. microsporus TB55 saat digunakan pada fermentasi tempe menghasilkan kualitas yang sesuai dengan syarat mutu tempe berdasarkan SNI 2015 kecuali dalam parameter warna. Ketiga jenis tempe yang dihasilkan berwarna kekuningan sementara berdasarkan SNI 2015 harus berwarna putih. Informasi tentang warna kuning tersebut perlu dikaji lebih lanjut.

\section{Daftar Pustaka}

Aderibigbe, E., Osegboun, A.O. 2006. Acceptability of tempeh among health workers in Ado-Ekiti, Nigeria. Pakistan Journal of Nutrition 5:122-12.
DOI:10.3923/pjn.2006.122.124.

AOAC (Association of Official Analytical Chemists). 2012. Official Methods of Analysis, 19th Edition. Arlington.

Astawan, M., Wresdiyati, T., Maknun, L. 2017. Tempe sumber zat gizi dan komponen bioaktif untuk kesehatan. IPB Press, Bogor.

Astuti, M., Meliala, A., Dalais, F.S., Wahlqvist, M.L. 2000. Tempe, a nutritious and healthy food from Indonesia. Asia Pacific Journal of Clinical Nutrition 9(4):322-325. DOI: 10.1046/j.1440-6047.2000.

Barus, T., Salim D.P., Hartanti A. T. 2019a. Kualitas tempe menggunakan Rhizopus delemar TB26 dan $R$. delemar TB37 yang diisolasi dari inokulum tradisional tempe "daun waru". Jurnal Aplikasi Teknologi Pangan 8 (4):143-148. DOI:10.17728/jatp.4449.

Barus, T., Maya, F., Hartanti, A.T. 2019b. Peran beberapa galur Rhizopus microsporus yang berasal dari "laru tradisional" dalam menentukan kualitas tempe. Jurnal Aplikasi Teknologi Pangan 8(1):17-22. DOI:10.17728/jatp.3761.

Barus, T., Halim, R., Hartanti, A.T., Saputra, P.K. 2019c. Genetic diversity of Rhizopus microsporus from traditional inoculum of tempeh in Indonesia based on ITS sequences and RAPD marker. Biodiversitas Journal of Biological Diversity 20(3):847-852. DOI:10.13057/biodiv/d200331.

Barus, T., Titarsole, N.N., Mulyono, N., Prasasty, V.D. 2019d. Tempeh antioxidant activity using DPPH method: Effects of fermentation, processing, and microorganisms. Journal of Food Engineering and Technology DOI:10.32732/jfet.2019.8.2.75

8(2):75-80.

Barus, T., Suwanto, A., Wahyudi, A.T., Wijaya, H. 2008. Role of bacteria in tempe bitter taste formation: microbiological and molecular biological analysis based on 16S rRNA gene. Microbiology Indonesia 2(1):17-21. DOI:10.5454/mi.2.1.4.

Endrawati, D., Kusumaningtyas, E. 2017. Beberapa fungsi Rhizopus sp dalam meningkatkan nilai nutrisi bahan pakan. WARTAZOA 27(2):081-088. DOI:10.14334/wartazoa.v27i2.1181.

Fiedor, J., Burda, K. 2014. Potential role of carotenoids as antioxidants in human health and disease. Nutrients 6(2):466-488. DOI:10.3390/nu6020466.

Handajani, Y.S., Turana, Y., Yogiara, Y., Widjaja, N.T., Sani, T.P., Christianto, G.A.M., Suwanto, A. 2020. Tempeh consumption and cognitive improvement in mild cognitive impairment. Dementia and geriatric cognitive disorders 49:497-502. DOI:10.1159/000510563.

Handoyo, T., Morita, N. 2006. Structural and functional properties of fermented soybean (tempeh) by using Rhizopus oligosporus. International Journal of Food Properties 9(2):347-355. DOI:10.1080/10942910500224746.

Haron, H., Shahar, S., O'Brien, K.O., Ismail, A., Kamaruddin, N., Rahman, S.A. 2010. Absorption of calcium from milk and tempeh consumed by postmenopausal Malay women using the dual 
stable isotope technique. International Journal of Food Sciences and Nutrition 61(2):125-137. DOI:10.3109/09637480903348080.

Hartanti, A.T., Rahayu, G., Hidayat, I. 2015. Rhizopus species from fresh tempeh collected from several regions in Indonesia. Hayati Journal Bioscience 22(3):136-142. DOI:10.1016/j. hjb. 2015.10.004.

Hsu, R.L., Lee, K.T., Wang, J.H., Lee, Y.L., Chen, P.Y. 2009. Amyloid-degrading ability of nattokinase from Bacillus subtilis natto. Journal of Agricutural Food Chemistry 57:503-8. DOI:10.1021/jf803072r.

Jennessen, J., Schnürer, J., Olsson, J., Samson, R.A., Dijksterhuis, J. 2008. Morphological characteristics of sporangiospores of the tempe fungus Rhizopus oligosporus differentiate it from other taxa of the $R$. microsporus group. Mycological Research 112(1):547-563. DOI:10.1016/j.mycres.2007.11.006.

Kadar, A.D., Astawan, M., Putri, S.P., Fukusaki, E., 2020. Metabolomics-Based study of the effect of raw materials to the end product of tempe-an Indonesian fermented soybean. Metabolites 10(9):1-11. DOI:10.3390/metabo10090367.

Kiers, J.L., Nout, R.M.J., Rombouts, F.M. 2000. In vitro digestibility of processed and fermented soya bean, cowpea and maize. Journal of The Science of Food and Agriculture 80(9):1325-1331. DOI:10.1002/1097-0010(200007)80:9.

Kim, M.R., Kawamura, Y., Lee, C.H. 2003. Isolation and identification of bitter peptides of tryptic hydrolysate of soybean $11 \mathrm{~S}$ glycinin by reversephase high-performance liquid chromatography. Journal of Food Science 68: 2416-2422. DOI:10.1111/j.1365-2621.2003.tb07039.x.

Kwon, G.H., Lee, H.A., Park, J.Y., Kim, J.S., Lim, J., Park, C.S., Kwon, D.Y., Kim, Y.S., Kim, J.H. 2009. Development of a PCR-RAPD method for identification of Bacillus species isolated from Cheonggukjang. International Journal of Food Microbiology 129: 282-7. DOI:10.1016/j.ijfoodmicro.2008.12.013.

Lawless, H.T., Heymann, H. 2010. Sensory evaluation of food: principles and practices. 2nd Ed. Springer Science Business Media, New York.

Kustyawati, M.E., Subeki, Murhadi, Rizal, S., Astuti P. 2020. Vitamin B12 production in soybean fermentation for tempeh. AIMS Agriculture and Food 5(2): 262-271. DOI:10.3934/agrfood.2020.2.262.

Myong, J.C., Unklesbay, N., Hsieh, F.H., Clarke, A.D. 2004. Hydrophobicity of bitter peptides from soy protein hydrolysates. Journal of Agricultural Food Chemistry 52:5895-5901.
Ningsih, T.E., Siswanto, Rudju, W. 2018. Aktivitas antioksidan kedelai edamame hasil fermentasi kultur campuran oleh Rhizopus oligosporus dan Bacillus subtilis. Sainstek 7(1):17-21. DOI:10.19184/bst.v6i1.7556.

Nout, M.J.R., Kiers, J.I. 2005. Tempe fermentation, innovation, and functionality: update into the third millenium. Applied and Environmental Microbiology 98:789-805. DOI:10.1111/j.13652672.2004.02471.x.

Nout, M.J.R., Rombouts, F.M. 1990. Recent developments in tempe research. Journal of Applied Bacteriology 69:609-633. DOI:10.1111/j.1365-2672.1990.tb01555.x.

Puspitasari, A., Astawan, M., Wresdiyati, T. 2020. Pengaruh Germinasi Kedelai terhadap Komposisi Proksimat dan Komponen Bioaktif Isoflavon Tempe Segar dan Semangit. Jurnal Pangan 29(1):35-44. DOI:10.33964/jp.v29i1.460.

Roubos van den Hill, P.J., Nout, M.J.R., Beumer, R., Meulen, J., Zwietering. 2009. Fermented soya bean (tempe) extracts reduce adhesion of enterotoxigenic Escherichia coli to intestinal epithelial cells. Journal of Applied Microbiology 106:1013-1021. DOI:10.1111/j.1365-2672.2008. 04068.x.

Sarkar, F.H., Li, Y. 2002. Mechanisms of cancer chemoprevention by soy isoflavone genistein. Cancer Metastasis Reviews 21(4):265-280. DOI:10.1023/a:1021210910821.

Schipper, M.A.A., Gauger, W., Ende, V.D.H. 1985. Hybridization of Rhizopus species. Microbiology 131(9):2359-2365. DOI:10.1099/00221287-1319-2359.

SNI (Standar Nasional Indonesia) 3144-2015. 2015. Tempe Kedelai. Badan Standarisasi Nasional. Jakarta.

Stephanie, T.S., Kartawidjajaputra, F., Silo, W., Yogiara, Y., Suwanto, A. 2019. Tempeh consumption enhanced beneficial bacteria in the human gut. Food Research 3(1): 57-63. DOI:10.26656/fr.2017.3(1).230

Sudaryatiningsih, C., Supyani, S. 2009. Linoleic and linolenic acids analysis of soybean tofu with Rhizopus oryzae and Rhizopus oligosporus as coagulant. Nusantara Bioscience 1(3): 110-116. DOI: 10.13057/nusbiosci/n010302.

Terlabie, N.N., Sakyi-Dawson, E., Amoa-Awua, W.K. 2006. The comparative ability of four isolates of Bacillus subtilis to ferment soybeans into dawadawa. International Journal of Food Microbiology 106:145-152. DOI:10.1016/j. ijfoodmicro.2005.05.021. DOI:10.1021/if0495035. 